\title{
Article \\ Characteristics and Risk Assessment of Soil Polluted by Lead around Various Metal Mines in China
}

\author{
Jing Shi ${ }^{1,2}$, Ping Du ${ }^{2, *}$, Huilong Luo ${ }^{2,3}$, Juan Chen ${ }^{2}$, Yunhui Zhang ${ }^{2}$, Minghong $\mathrm{Wu}^{1}$ and Gang $\mathrm{Xu}^{1}$ \\ 1 School of Environmental and Chemical Engineering, Shanghai University, Shanghai 200444, China; \\ sj960314skinner@outlook.com (J.S.); mhwu@shu.edu.cn (M.W.); xugang@shu.edu.cn (G.X.) \\ 2 Technical Centre for Soil, Agriculture and Rural Ecology and Environment, \\ Ministry of Ecology and Environment, Beijing 100012, China; huilong.luo@mail.bnu.edu.cn (H.L.); \\ chenjuan@craes.org.cn (J.C.); lchjj2012@163.com (Y.Z.) \\ 3 College of Water Science, Beijing Normal University, Beijing 100875, China \\ * Correspondence: duping@craes.org.cn
}

check for updates

Citation: Shi, J.; Du, P.; Luo, H.; Chen, J.; Zhang, Y.; Wu, M.; Xu, G. Characteristics and Risk Assessment of Soil Polluted by Lead around Various Metal Mines in China. Int. J. Environ. Res. Public Health 2021, 18, 4598. https://doi.org/10.3390/ ijerph18094598

Academic Editor: Remigio

Paradelo Núñez

Received: 5 March 2021

Accepted: 24 April 2021

Published: 26 April 2021

Publisher's Note: MDPI stays neutral with regard to jurisdictional claims in published maps and institutional affiliations.

Copyright: (c) 2021 by the authors. Licensee MDPI, Basel, Switzerland. This article is an open access article distributed under the terms and conditions of the Creative Commons Attribution (CC BY) license (https:// creativecommons.org/licenses/by/ $4.0 /)$.

\begin{abstract}
The contamination of soil by lead $(\mathrm{Pb})$ is a serious and widespread problem in China, especially in mining areas. This paper summarized the available data regarding $\mathrm{Pb}$-contaminated soils around various metal mines in China. Based on these data, the $\mathrm{Pb}$ concentration in the soil and its temporal and spatial changes were analyzed. Potential ecological hazards and adult lead models were also used to estimate ecological and health risks. The results indicated that the concentration of $\mathrm{Pb}$ was closely related with the type of mine. Compared with other types of mine, soil around lead-zinc $(\mathrm{Pb}-\mathrm{Zn})$ and tin $(\mathrm{Sn})$ mines with high $\mathrm{Pb}$ contents in the metallic ores and high pollutant emission coefficient were more strongly polluted by $\mathrm{Pb}$. The characteristic spatial and temporal variations of $\mathrm{Pb}$ pollution status in China were clarified, and the results showed that the concentration was high in the southern, southwestern, and central regions of China where many mining areas were located, and the mean value passed a turning point in 2012. Ecological risk assessments indicated that some areas around mines were at considerable to high risk, and the risk was relatively severe in $\mathrm{Pb}-\mathrm{Zn}$ mining areas. According to the adult lead model, $\mathrm{Pb}-\mathrm{Zn}$ mines had a greater impact on blood $\mathrm{Pb}$ concentration than the other types of mine.
\end{abstract}

Keywords: blood lead level; ecological risk; metal mine; pollution characteristics; soil lead

\section{Introduction}

Lead $(\mathrm{Pb})$ is considered one of the most toxic trace elements in the environment, and it potentially can cause serious health problems in humans, animals, and plants [1-4]. Many studies have investigated the pollution of soil with $\mathrm{Pb}$, including environmental and health issues across China. According to the first National Soil Pollution Investigation of China, $1.5 \%$ of all soil samples were contaminated with $\mathrm{Pb}$ [5] and mining activities were considered one of the most significant sources of heavy metal contamination among human industrial, mining, and farming activities. According to statistics, China is rich in mineral resources, and $\mathrm{Pb}$ reserves and output rank among the top in the world [6]. Heavy metals may be released into the surrounding environment during the mining process and finally accumulate in soil, thereby resulting in high soil $\mathrm{Pb}$ concentrations around mining areas $[7,8]$. Learning from most studies of the pollution of soils with heavy metals related to mining activities in recent years, $\mathrm{Pb}-\mathrm{Zn}$ mines are considered to have a serious impact on soil $\mathrm{Pb}$ pollution [9-11]. In addition, risk assessments have been conducted regarding the pollution of soil with heavy metals from mines. Li et al. [12] performed pollution and health risk assessments for soils in 72 mining areas and proposed that $\mathrm{Pb}$, cadmium, arsenic, and other pollutants should be prioritized for control. These conclusions are very important for determining the key elements that need to be controlled during environment management.

Most of the studies mentioned above focused on only a single or several mining areas, whereas few have considered the different contributions and impacts of multiple 
mines. Thus, a comprehensive pollution assessment is urgently needed on a national scale for mining areas in China, especially determining the differences in the potential risk associated with various mines. The aims of this research were: (1) to evaluate the soil $\mathrm{Pb}$ pollution around various metal mines in China; (2) to analyze the ecological risks and blood lead levels (BLLs) associated with different types of mines; and (3) to propose policy recommendations for relevant agencies. The conclusions obtained in this study could be useful for developing management policies and control measures for different mines.

\section{Materials and Methods}

\subsection{Data Collection and Analysis}

Using the search terms "Pb, soil, mine, China", 154 papers (Table S1) published between 2002 and 2016 were collected from the Web of Science, Elsevier Science Direct, Chinese Periodical Full-text, China National Knowledge Infrastructure (CNKI), Science Online, and other sources. The samples were all surface soil samples (depths of $0-15 \mathrm{~cm}$ or 0-20 cm) obtained using conventional sampling methods, such as snake-type sampling, gridding sampling, multipoint sampling, and random sampling. The samples were mainly analyzed by inductively coupled plasma-mass spectrometry, graphite furnace atomic absorption spectrophotometry, or atomic absorption spectroscopy. The average values recorded in previous studies were used to represent the concentrations at the sampling sites (Table S1).

In total, 258 sites with $\mathrm{Pb}$ contaminated soils were identified in studies of mining areas distributed across 21 provinces throughout China (Figure 1). Each study investigated only one or a few sites with suspected $\mathrm{Pb}$ contamination. Based on these studies, we conducted a relatively comprehensive, national-scale assessment of $\mathrm{Pb}$ contamination in soils around typical metal mines in China.

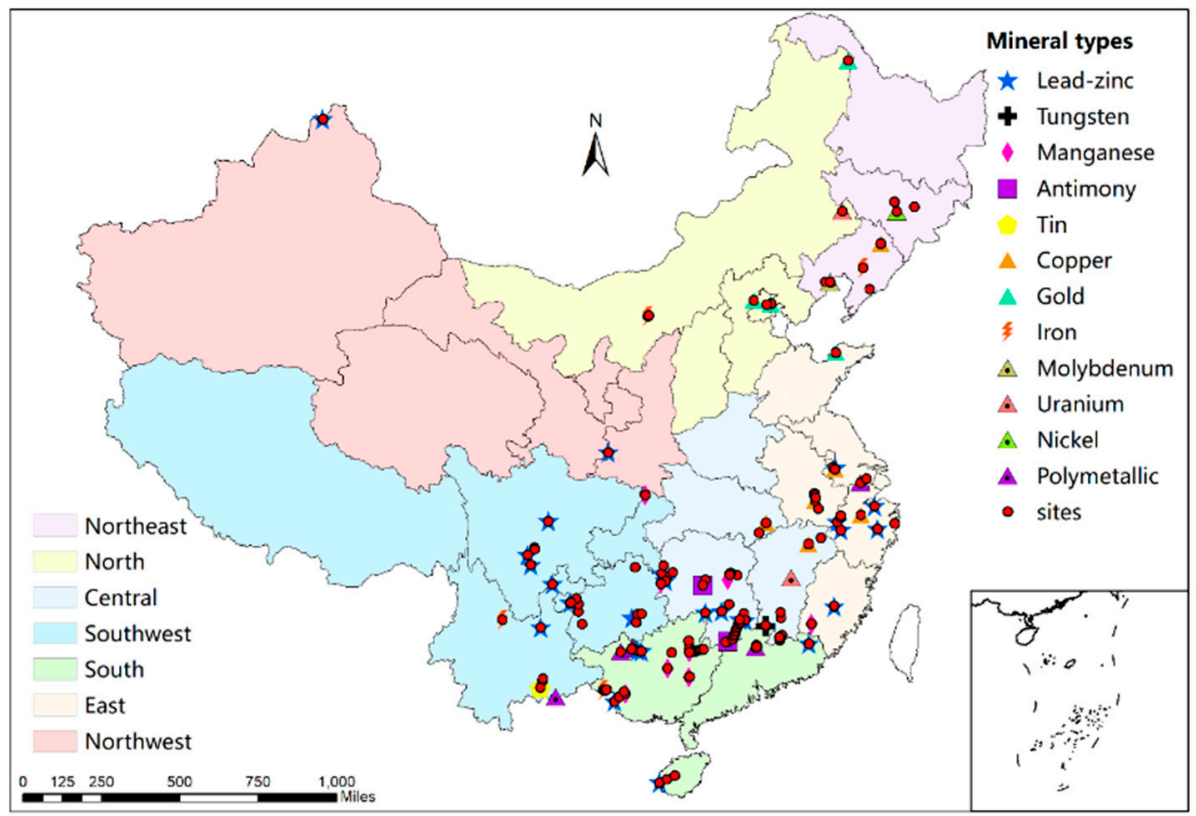

Figure 1. Distributions of sites and different mining areas in China.

\subsection{Ecological Risk Assessment}

The ecological risk index developed by Hakanson has been used widely to evaluate the potential ecological hazard due to heavy metals [13-15]. This method combines environmental chemistry, biotoxicology, and ecology to assess the effects of various pollutants 
and the comprehensive effects of various pollutants. The ecological risk index is calculated as follows:

$$
E_{f}^{i}=T_{i} \times \frac{C_{i}}{C_{0}} R I=\sum_{i=0}^{n} E_{f}^{i}
$$

where $E_{f}^{i}$ and $R I$ are the single ecological risk index and multiple ecological risk index, respectively, $C_{i}$ is the concentration of $\mathrm{Pb}$ measured in soil $(\mathrm{mg} / \mathrm{kg}), C_{0}$ is the reference value, i.e., the screening value for the soil environmental quality standard (GB 15618-2018), and $T_{i}$ is the toxicity response coefficient. The toxicity response coefficient for $\mathrm{Pb}$ is 5 based on Hakanson's standardized toxicity response coefficient. The risk classes based on $E_{f}^{i}$ can be classified into five levels (Table 1; Wang et al. [16]).

Table 1. Hankanson's potential ecological hazard assessment index classes.

\begin{tabular}{cc}
\hline Potential Ecological Hazard Coefficient $\left(E_{f}^{i}\right)$ & Potential Ecological Hazard Degree \\
\hline$E_{f}^{i}<40$ & Low risk \\
$40 \leq E_{f}^{i}<80$ & Moderate risk \\
$80 \leq E_{f}^{i}<160$ & Considerable risk \\
$160 \leq E_{f}^{i}<320$ & High risk \\
$E_{f}^{i} \geq 320$ & Extreme high risk \\
\hline
\end{tabular}

\subsection{Adult Lead Model (ALM)}

The ALM was developed to estimate the blood lead level (BLL) from non-contact intensive indoor occupational exposure to contaminated soil at Superfund sites in the United States [17]. The residents near mining areas could experience significant and chronic exposure to contaminated soil, which we assumed would be similar to the exposure scenario for the ALM. The ALM uses a simplified biokinetic model to predict the quasisteady state BLL for adults under chronic exposure to lead-contaminated soil [18]. It involves the process of soil ingestion, absorption after ingestion, and conversion into blood lead after absorption. The basic formula [19] is as follows:

$$
P b B_{\text {adult,central }}=P b B_{a d u l t, 0}+\frac{P b S \cdot B K S F \cdot I R_{S} \cdot A F_{S} \cdot E F_{S}}{A T}
$$

where $P b B_{a d u l t, c e n t r a l}$ is the central estimate of the blood lead concentration $(\mu \mathrm{g} / \mathrm{dL})$ in adults, $P b B_{a d u l t, 0}$ is the typical blood lead concentration $(\mu \mathrm{g} / \mathrm{dL})$ in adults, $\mathrm{PbS}$ is the soil lead concentration $(\mu \mathrm{g} / \mathrm{g}), B K S F$ is the biokinetic slope factor $(\mu \mathrm{g} / \mathrm{dL}$ blood lead increase per $\mu \mathrm{g} /$ day lead uptake), $I R_{S}$ is the intake rate of soil (g/day), $A F_{S}$ is the absolute gastrointestinal absorption fraction (unitless), $E F_{S}$ is the exposure frequency for contact with the assessed soil (days/year for long term exposure), and $A T$ is the averaging time (days/year). Table S2 provides more information about these parameters.

\subsection{Statistical Analysis}

The normality test was conducted before making comparisons of $\mathrm{Pb}$ concentrations in regional distribution and temporal trend. $\mathrm{Pb}$ concentrations in different regions did not comply with the normal distribution. Therefore, there was no difference analysis between different regions, just a statistic. All statistical analyses were conducted using SPSS.

\section{Results and Discussion}

\subsection{Pollution Status of Soil Pb around Mines in China}

In total, 63 major metal mines were identified in 21 provinces throughout China in this study (Figure 1). In total, 11 types of mines were identified and the main types were $\mathrm{Pb}-\mathrm{Zn}$, Sn, tungsten $(\mathrm{W})$, copper $(\mathrm{Cu})$, manganese $(\mathrm{Mn})$, gold $(\mathrm{Au})$, antimony $(\mathrm{Sb})$, and iron (Fe) mines (Table S3). The sites considered were mainly located in southern and central 
China, but especially in Hunan and Guangxi provinces, which are rich in mineral resources and the locations of non-ferrous metal reserves [20,21]. Based on the distribution of mining areas and the geographical division of China, five regions were investigated in this review. As shown in Figure 2, the $\mathrm{Pb}$ concentrations varied among the five regions investigated. The median concentration in all regions was between the screening value and control value (China soil environment quality standard, GB15618-2018). The southern, southwestern, and central regions have relatively higher levels of $\mathrm{Pb}$ contamination than other regions, and this pattern is closely related to the distribution of mines in China.

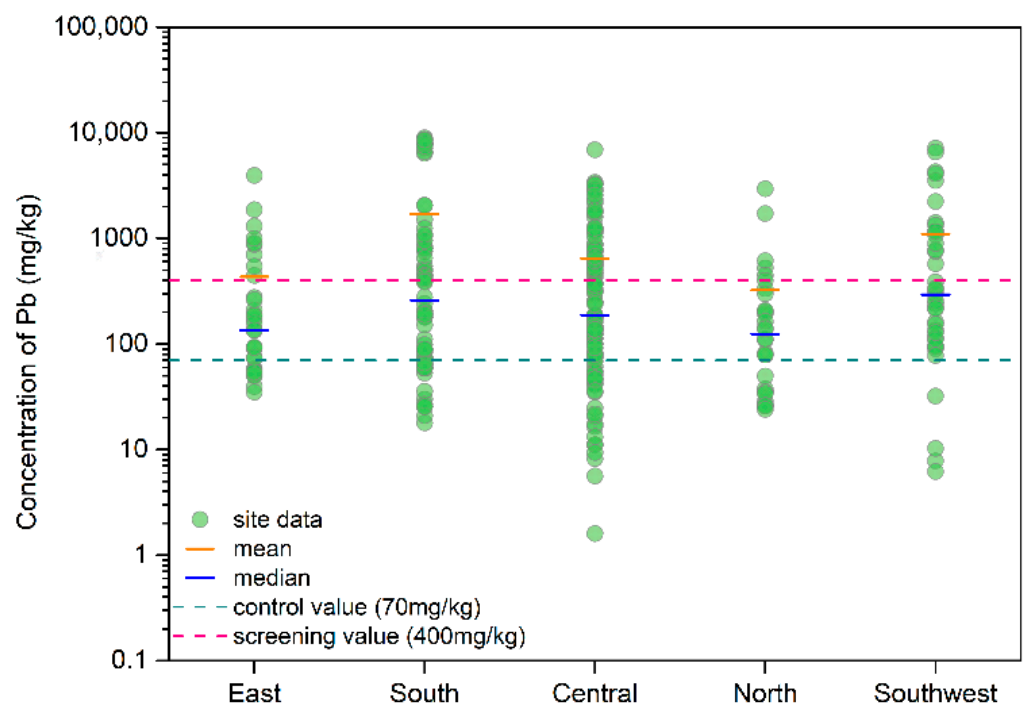

Figure 2. Regional distribution of $\mathrm{Pb}$ concentrations (East region includes Zhejiang, Anhui, Shanghai, Jiangxi, Shandong, Jiangsu and Fujian provinces. South region includes Guangxi, Guangdong and Hainan provinces. Central region includes Hunan, Hubei and Henan provinces. North region includes Shanxi, Shaanxi, Hebei, Beijing, Tianjin, Inner Mongolia, Jilin, Heilongjiang and Liaoning provinces. Southwest region includes Yunnan, Guizhou, Chongqing and Sichuan provinces).

In this study, the screening $(70 \mathrm{mg} / \mathrm{kg})$ and control $(400 \mathrm{mg} / \mathrm{kg})$ values were used as references to assess the $\mathrm{Pb}$ contamination in soils (China soil environment quality standard, GB15618-2018). The results showed that $76.9 \%$ of the sites exceeded the screening value and $38.5 \%$ exceeded the control value. The mean $\mathrm{Pb}$ concentration was $542.1 \mathrm{mg} / \mathrm{kg}$, which was about 7.7 times larger than the screening value and 1.4 times larger than the control value. Compared with Li et al.'s study [12] on heavy metal pollution in China's mining areas, the results in this study had lower $\mathrm{Pb}$ concentrations. The highest value was 102.4 times larger than the screening value, and it was reported in the $\mathrm{Pb}-\mathrm{Zn}$ mining area of Sichuan Province. The mean concentrations of $\mathrm{Pb}$ in agricultural soil in China range from 32 to $93.89 \mathrm{mg} / \mathrm{kg}$ (37.55 mg/kg, Wei et al. [22]; $48.43 \mathrm{mg} / \mathrm{kg}$, Yang et al., [23]; $32 \mathrm{mg} / \mathrm{kg}$, Huang et al. [24]; $93.89 \mathrm{mg} / \mathrm{kg}$, Yang et al. [25]). Therefore, the $\mathrm{Pb}$ concentrations in the soils around mines are clearly higher than those in agricultural soil, mainly due to the pollution that occurs during mining activities, such as ore excavation and transportation, smelting, refining, and tailings [26].

Atmospheric emissions are an important source of soil $\mathrm{Pb}$ [27]. Generally speaking, the concentration of lead in the atmosphere near the mining area is relatively high, and atmospheric deposition as the main source has adverse effects on soil [28-30]. Statistical data on $\mathrm{Pb}$ emissions shows that atmospheric emissions showed a cliff-jumping decline in 2000 but increased gradually from 2001 to 2016. Leaded gasoline was phased out in 2000, so the atmospheric $\mathrm{Pb}$ emissions dropped suddenly. Subsequently, due to emissions from other sources such as coal combustion and non-ferrous smelting, the atmospheric $\mathrm{Pb}$ emissions slowly increased again [31,32]. In terms of temporal change, the $\mathrm{Pb}$ concentrations in soils around mining areas increased gradually from 2002 to 2012, and decreased slowly from 
2012 to 2016 (Figure 3). This trend was consistent with that in the atmospheric emissions of $\mathrm{Pb}$ from 2002 to 2012, which also indicates that atmospheric $\mathrm{Pb}$ emissions were a significant source of soil $\mathrm{Pb}$. According to the report by Shi et al. [33], Pb concentration peaked in 2006-2010, and a decrease was observed during 2011-2016, which was consistent with the results of this paper. Recently, the Chinese government adopted a series of measures to cut off the source of pollution, speed up the remediation process, and avoid further pollution, especially the 12th Five Year Plan for the control and abatement of heavy metals, which was implemented from 2011. Thus, soil $\mathrm{Pb}$ pollution has been controlled well in recent years.

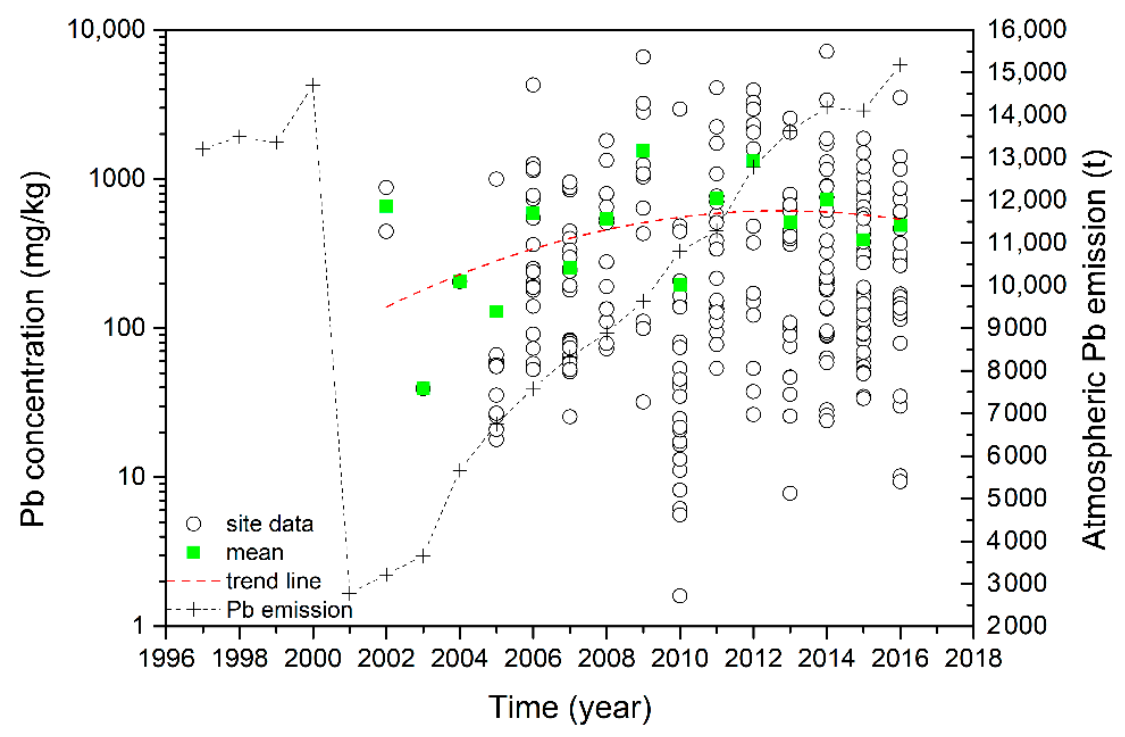

Figure 3. Temporal trend in $\mathrm{Pb}$ concentration $(\mathrm{mg} / \mathrm{kg})$ in soils in mining areas and annual atmospheric emissions of $\mathrm{Pb}(\mathrm{t})$.

\subsection{Characteristics of Soil Pb Pollution around Metal Mines}

The soil pollution around some types of mines (i.e., around $\mathrm{Pb}-\mathrm{Zn}$ and $\mathrm{Sn}$ mines) was relatively severe, and there was an obvious relationship between $\mathrm{Pb}$ pollution and different types of mines (Figure S1). The soil $\mathrm{Pb}$ pollution levels at eight types of metal mines are shown in Figure 4. The concentrations of $\mathrm{Pb}$ were relatively high around $\mathrm{Pb}-\mathrm{Zn}$ and Sn mines, with average concentrations of 1095.7 and $551.43 \mathrm{mg} / \mathrm{kg}$, respectively. In addition, the average concentrations of $\mathrm{Pb}$ around $\mathrm{Au}$ and $\mathrm{Mn}$ mines were about 358.8 and $294.55 \mathrm{mg} / \mathrm{kg}$, respectively, whereas the soil $\mathrm{Pb}$ contents were relatively lower around $\mathrm{Cu}$, $\mathrm{Sb}, \mathrm{Fe}$, and $\mathrm{W}$ mines.

According to Table 2, different mines have different geological characteristics and contain different associated heavy metals. Among them, $\mathrm{Pb}$ is the main heavy metal element in $\mathrm{Pb}-\mathrm{Zn}$ mines. In addition, $\mathrm{Pb}$ is sometimes found in $\mathrm{Sn}, \mathrm{Mn}$, and $\mathrm{Au}$ mines. Analyzing the pollutant emission coefficients for industrial pollution sources showed that $\mathrm{Pb}-\mathrm{Zn}$ mines had the highest $\mathrm{Pb}$ emission coefficient $(0.262 \mathrm{~g} / \mathrm{t})$ among all of the mine types. The pollutant emission coefficient for $S n$ mines was $0.022 \mathrm{~g} / \mathrm{t}$, which was also much higher than that for other mine types (Table S4). It should be noted that the pollution coefficients of small and medium Sn mines were much higher than those for $\mathrm{Pb}-\mathrm{Zn}$ mines, and some small-scale Sn mines had pollutant emission coefficients as high as $13.445 \mathrm{~g} / \mathrm{t}$. The annual output of Fe was 760 million tons and that of refined $\mathrm{Cu}$ was 9.029 million tons, but they caused far less pollution than $\mathrm{Pb}-\mathrm{Zn}$ and $\mathrm{Sn}$ mines. The $\mathrm{Pb}$ emission coefficient for $\mathrm{Cu}$ mines was only $0.004 \mathrm{~g} / \mathrm{t}$, so the high-yield $\mathrm{Cu}$ mines were less polluting. In previous studies and investigations of Fe mines, $\mathrm{Pb}$ was not listed as the subject of investigation, thereby indicating that $\mathrm{Pb}$ pollution is not a concern around Fe mines. It can be seen that, without affecting the output, solving the problem of high pollutant emission coefficients in the mining process is also a good way to prevent pollution. 


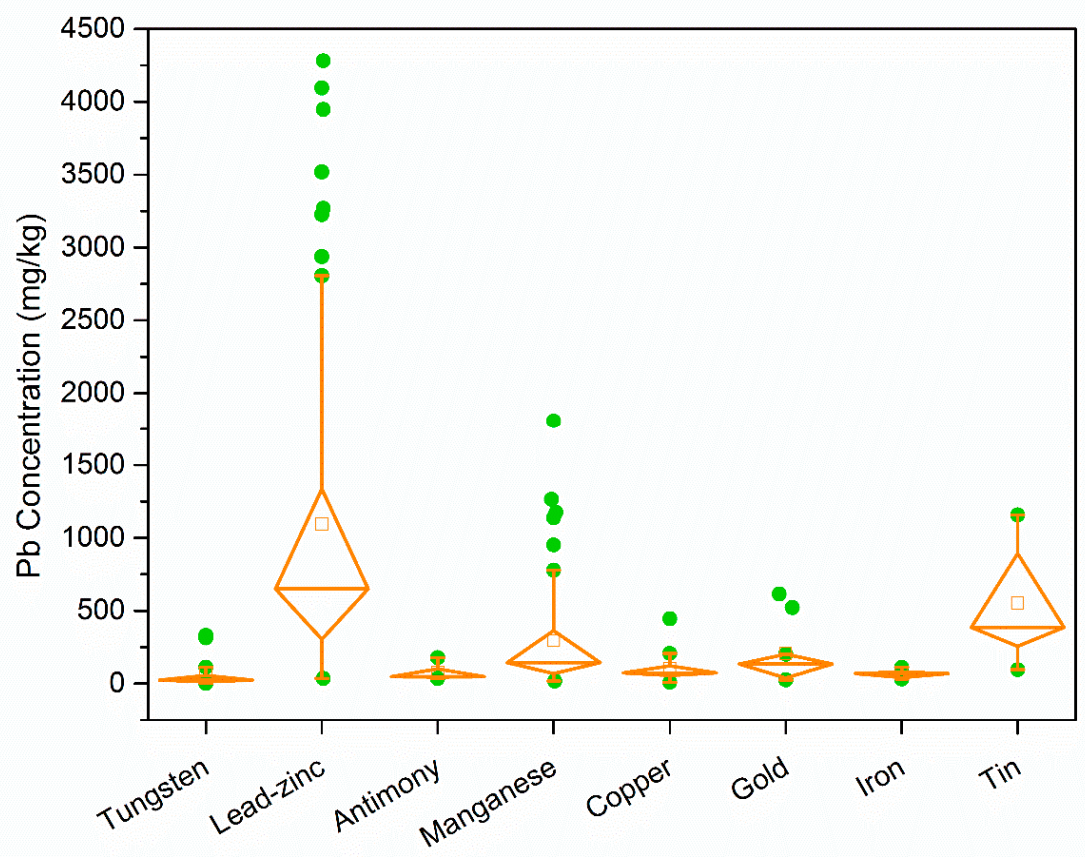

Figure 4. $\mathrm{Pb}$ concentrations in soil around different types of mines.

Table 2. Geological characteristics of various metal mines.

\begin{tabular}{cc}
\hline Type of Mine & Major Associated Metals \\
\hline Tungsten $(\mathrm{W})$ & $\mathrm{W}, \mathrm{Sn}, \mathrm{Mo}, \mathrm{Bi}$ \\
Lead-Zinc $(\mathrm{Pb}-\mathrm{Zn})$ & $\mathrm{Pb}, \mathrm{Zn}, \mathrm{Cd}, \mathrm{Au}, \mathrm{Ag}, \mathrm{Cu}, \mathrm{Sn}$ \\
Antimony $(\mathrm{Sb})$ & $\mathrm{Sb}, \mathrm{Au}, \mathrm{W}$ \\
Manganese $(\mathrm{Mn})$ & $\mathrm{Mn}, \mathrm{Co}, \mathrm{Ni}, \mathrm{Cu}, \mathrm{Pb}, \mathrm{Zn}$ \\
Copper $(\mathrm{Cu})$ & $\mathrm{Cu}, \mathrm{Mo}, \mathrm{Au}, \mathrm{Ag}$ \\
Gold $(\mathrm{Au})$ & $\mathrm{Au}, \mathrm{Ag}, \mathrm{Cu}, \mathrm{Zn}, \mathrm{Pb}, \mathrm{Pt}$ \\
Iron $(\mathrm{Fe})$ & $\mathrm{Fe}, \mathrm{Cu}, \mathrm{Ni}$ \\
Tin $(\mathrm{Sn})$ & $\mathrm{Sn}, \mathrm{Pb}, \mathrm{W}, \mathrm{Bi}, \mathrm{Cd}, \mathrm{Ag}, \mathrm{Cu}$ \\
\hline
\end{tabular}

Mo (Molybdenum), Bi (Bismuth), Cd (Cadmium), Ag (Silver), Co (Cobalt), Ni (Nickel), Pt (Platinum).

\subsection{Ecological Risk Assessment}

The calculated ecological risk indexes showed that most of the sites were at low risk, where this class accounted for $72.1 \%$, but about $13.6 \%$ of the sites were at considerable and high risk (Figure 5). The results also showed that the $\mathrm{Pb}$ pollution around $\mathrm{Pb}-\mathrm{Zn}$ mines was mainly classified as low or moderate risk. Overall, $29.3 \%$ of the sites were at considerable to high risk. Due to the high $\mathrm{Pb}$ emission coefficient for $\mathrm{Sn}$ mines, the pollution was mainly at low to considerable risk. Other mines were basically at low risk. Therefore, greater ecological risks were detected around $\mathrm{Pb}-\mathrm{Zn}$ mines and $\mathrm{Sn}$ mines.

\subsection{Assessment of Adult BLLs}

Blood $\mathrm{Pb}$ poisoning is considered the biggest health problem caused by exposure to soil contaminated with $\mathrm{Pb}[34,35]$. As shown in Figure 6, most of the sites were lower than the threshold value $(100 \mu \mathrm{g} / \mathrm{L})$ for China. In fact, about $83.72 \%$ of the sites had BLLs less than $50 \mu \mathrm{g} / \mathrm{L}$ and only $3.88 \%$ of the sites at Pb-Zn mines had BLLs higher than $100 \mu \mathrm{g} / \mathrm{L}$. As showed in Figure 6, it can be concluded that that $\mathrm{Pb}-\mathrm{Zn}$ mines had a greater impact on BLLs than the other types of mine. Only one $\mathrm{Pb}-\mathrm{Zn}$ mine in Sichuan province had sites with BLLs above $100 \mu \mathrm{g} / \mathrm{L}$. Thus, the soil $\mathrm{Pb}$ in mining areas did not pose a significant health risk to the human body. 


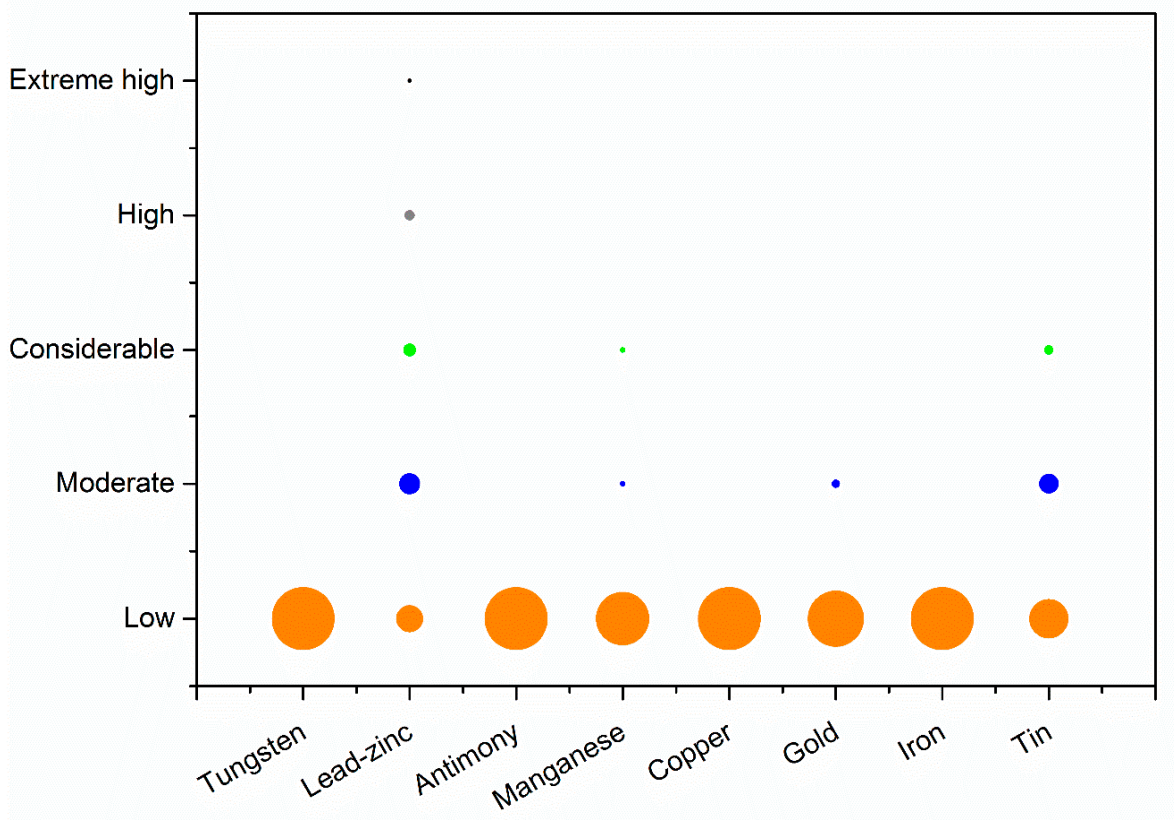

Figure 5. Ecological risk indexes for different types of mines.

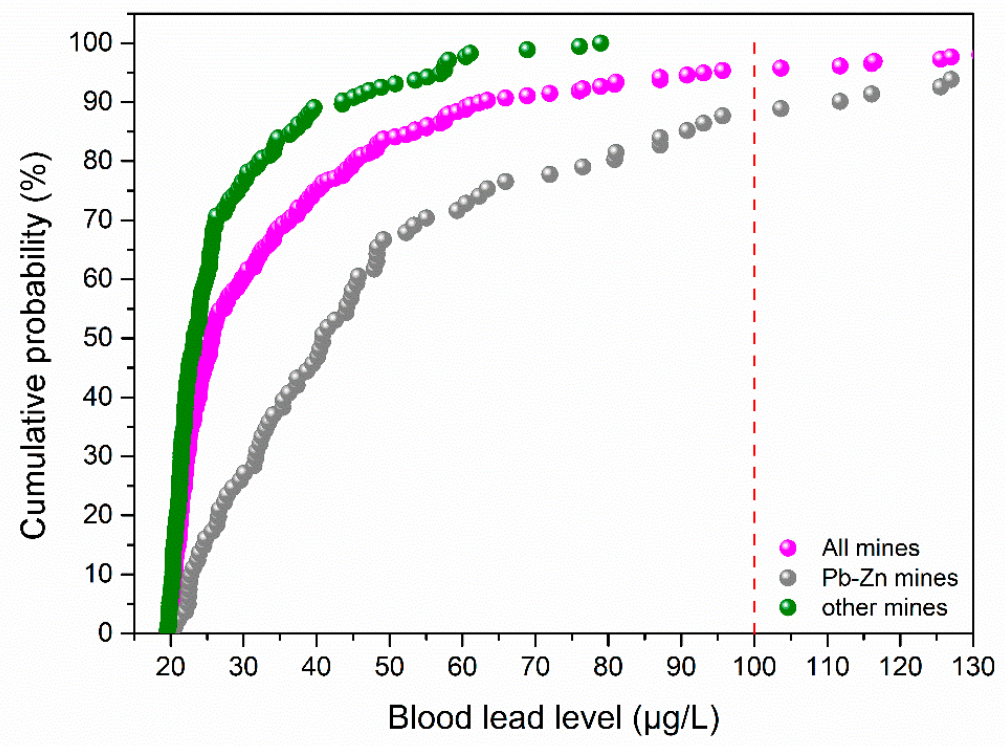

Figure 6. Cumulative probabilities of adult blood lead levels in mining areas.

However, it has been reported that serious cognitive impairment and neurobehavioral deficits can occur if the BLL is lower than $100 \mu \mathrm{g} / \mathrm{L}$, or even $50 \mu \mathrm{g} / \mathrm{L}$ [36]. The threshold value for Germany $(35 \mu \mathrm{g} / \mathrm{L})$ and USA $(50 \mu \mathrm{g} / \mathrm{L})$ are both lower than that in China $[37,38]$. There is still no internationally recognized blood $\mathrm{Pb}$ poisoning threshold [39]. Thus, the higher level of $100 \mu \mathrm{g} / \mathrm{L}$ applied in China may underestimate the health risks caused by $\mathrm{Pb}$ contaminated soil. In future research, we need to pay more attention to mining areas with BLLs above $50 \mu \mathrm{g} / \mathrm{L}$. Relevant departments can make further adjustments to the assessment threshold of BLL according to the actual situation in China.

\section{Conclusions}

This study reviewed $\mathrm{Pb}$ contamination in soils around typical metal mines in China. The results showed that the soils around mining areas are quite polluted, particularly in the southern, southwestern, and central regions of China, and the soil $\mathrm{Pb}$ concentrations 
are strongly associated with the type of mine. The pollution levels around the eight typical mine types from high to low are: $\mathrm{Pb}-\mathrm{Zn}>\mathrm{Sn}>\mathrm{Au}>\mathrm{Mn}>\mathrm{Cu}>\mathrm{Sb}>\mathrm{Fe}>\mathrm{W}$ mines. Temporal analysis indicated that the soil $\mathrm{Pb}$ is related to atmospheric $\mathrm{Pb}$ emissions. Without affecting the production cost and output, taking environmentally sustainable mining technologies is the first choice to reduce the $\mathrm{Pb}$ emission coefficient. In addition, the corresponding departments should strengthen the inspection of the process of $\mathrm{Pb}-\mathrm{Zn}$ mining and the supervision of the pollution effects. Ecological risk assessment indicated that the risk is relatively severe for Pb- $\mathrm{Zn}$ and $\mathrm{Sn}$ mines. The ALM model showed that the soil around mining areas has a very limited impact on the BLL, but the impact of $\mathrm{Pb}-\mathrm{Zn}$ mines is greater than those of other mines. In general, risk management for $\mathrm{Pb}-\mathrm{Zn}$ mines should receive more attention in the future. It is necessary to interrupt the exposure pathway and prevent people from exposure to high-risk contaminated soil.

Supplementary Materials: The following are available online at https:/ / www.mdpi.com/article/10 .3390 /ijerph18094598/s1, Figure S1: Pollution situation around different mining areas, Table S1: Basic information of soils in 154 examined areas in China, Table S2: Parameters of blood lead model in this study, Table S3: Basic information of 63 major mining areas, Table S4: Lead pollution and emission coefficients of different min-ing industries, Table S5: Data extracted from the literature, Table S6: Data analysis results (unit: $\mathrm{mg} / \mathrm{kg}$ ), Table S7: Data of different regions (unit: $\mathrm{mg} / \mathrm{kg}$ ), Table S8: Data of different years (unit: $\mathrm{mg} / \mathrm{kg}$ ), Table S9: Data of different mining areas (unit: $\mathrm{mg} / \mathrm{kg}$ ).

Author Contributions: Conceptualization and writing-original draft preparation, J.S.; data analysis and visualization, J.S.; writing - review and editing, P.D.; methodology, J.S., P.D. and H.L.; software, Y.Z. and J.C.; validation, M.W. and G.X. All authors have read and agreed to the published version of the manuscript.

Funding: This study was supported by the National Natural Science Foundation of China (No. 41501350), National Key Research and Development Project (No. 2020YFC1806304), and the Major projects of Guangxi Scientific Research and Technology Development Plan (No. 1598014-4).

Data Availability Statement: The data presented in this study are available in supplementary material.

Conflicts of Interest: The authors declare no conflict of interest.

\section{References}

1. Zulfiqar, U.; Farooq, M.; Hussain, S.; Maqsood, M.; Hussain, M.; Ishfaq, M.; Ahmad, M.; Anjum, M.Z. Lead toxicity in plants: Impacts and remediation. J. Environ. Manag. 2019, 250, 109557. [CrossRef] [PubMed]

2. Charkiewicz, A.E.; Backstrand, J.R. Lead Toxicity and Pollution in Poland. Int. J. Environ. Res. Public Health 2020, $17,4385$. [CrossRef] [PubMed]

3. Ebrahimi, M.; Khalili, N.; Razi, S.; Keshavarz-Fathi, M.; Khalili, N.; Rezaei, N. Effects of lead and cadmium on the immune system and cancer progression. J. Environ. Health Sci. Eng. 2020, 18, 335-343. [CrossRef] [PubMed]

4. Vatanpour, N.; Feizy, J.; Hedayati Talouki, H.; Es'haghi, Z.; Scesi, L.; Malvandi, A.M. The high levels of heavy metal accu-mulation in cultivated rice from the Tajan river basin: Health and ecological risk assessment. Chemosphere 2020, 245, 125639. [CrossRef]

5. MEP and MLR. 2014. Available online: http://english.mee.gov.cn/News_service/news_release/201404/t20140428_271088.shtml (accessed on 28 April 2014).

6. MNR. China Mineral Resources. Available online: http://www.mnr.gov.cn/sj/sjfw/kc_19263/zgkczybg/201910/t20191022_24 73040.html (accessed on 22 October 2019).

7. Zhang, X.W.; Yang, L.S.; Li, Y.H.; Li, H.R.; Wang, W.Y.; Ye, B.X. Impacts of lead/zinc mining and smelting on the environ-ment and human health in China. Environ. Monit. Assess. 2012, 184, 2261-2273. [CrossRef]

8. Wang, S.; Zheng, K.; Liu, Q.; Wang, L.; Feng, X.; Li, H. Galena weathering in simulated alkaline soil: Lead transformation and environmental implications. Sci. Total Environ. 2021, 755, 142708. [CrossRef]

9. Qi, J.; Zhang, H.; Li, X.; Lu, J.; Zhang, G. Concentrations, spatial distribution, and risk assessment of soil heavy metals in a Zn-Pb mine district in southern China. Environ. Monit. Assess. 2016, 188, 413. [CrossRef]

10. Wang, Y.; Wang, R.; Fan, L.; Chen, T.; Bai, Y.; Yu, Q.; Liu, Y. Assessment of multiple exposure to chemical elements and health risks among residents near Huodehong lead-zinc mining area in Yunnan, Southwest China. Chemosphere 2017, 174, 613-627. [CrossRef]

11. Du, Y.; Chen, L.; Ding, P.; Liu, L.; He, Q.; Chen, B.; Duan, Y. Different exposure profile of heavy metal and health risk be-tween residents near a $\mathrm{Pb}-\mathrm{Zn}$ mine and a Mn mine in Huayuan County, South China. Chemosphere 2019, 216, 352-364. [CrossRef]

12. Li, Z.; Ma, Z.; van der Kuijp, T.J.; Yuan, Z.; Huang, L. A review of soil heavy metal pollution from mines in China: Pollution and health risk assessment. Sci. Total Environ. 2014, 468-469, 843-853. [CrossRef] [PubMed]

13. Hakanson, L. An ecological risk index for aquatic pollution control.a sedimentological approach. Water Res. 1980, 14, 975-1001. [CrossRef] 
14. Li, X.; Zhang, J.; Gong, Y.; Yang, S.; Ye, M.; Yu, X.; Ma, J. Status of mercury accumulation in agricultural soils across China (1976-2016). Ecotoxicol. Environ. Saf. 2020, 197, 110564. [CrossRef]

15. Li, X.; Zhang, J.; Gong, Y.; Liu, Q.; Yang, S.; Ma, J.; Zhao, L.; Hou, H. Status of copper accumulation in agricultural soils across China (1985-2016). Chemosphere 2020, 244, 125516. [CrossRef] [PubMed]

16. Wang, Y.; Yang, L.; Kong, L.; Liu, E.; Wang, L.; Zhu, J. Spatial distribution, ecological risk assessment and source identifica-tion for heavy metals in surface sediments from Dongping Lake, Shandong, East China. CATENA 2015, 125, 200-205. [CrossRef]

17. United States Environmental Protection Agency (USEPA). Recommendations of the Technical Review Workgroup for Lead for an Approach to Assessing Risks Associated with Adult Exposures to Lead in Soil; USEPA: Washington, DC, USA. Available online: https:/ / semspub.epa.gov/work/HQ/174559.pdf (accessed on 1 January 2003).

18. Maddaloni, M.; Ballew, M.; Diamond, G.; Follansbee, M.; Gefell, D.; Goodrum, P.; Johnson, M.; Koporec, K.; Khoury, G.; Luey, J.; et al. Assessing Lead Risks at Non-Residential Hazardous Waste Sites. Hum. Ecol. Risk Assess. Int. J. 2005, 11, 967-1003. [CrossRef]

19. Zajac, L.; Kobrosly, R.W.; Ericson, B.; Caravanos, J.; Landrigan, P.J.; Riederer, A.M. Probabilistic estimates of prenatal lead exposure at 195 toxic hotspots in low- and middle-income countries. Environ. Res. 2020, 183, 109251. [CrossRef] [PubMed]

20. Huang, S.; Yang, Y.; Li, Q.; Zhao, D.; Wan, W. Spatial distribution and ecological risk assessment of heavy metals in soil around lead-zinc mining area. Environ. Sci. Technol. 2016, 39, 186-192.

21. Li, X.; Zhao, Z.; Yuan, Y.; Wang, X.; Li, X. Heavy metal accumulation and its spatial distribution in agricultural soils: Evi-dence from Hunan province, China. RSC Adv. 2018, 8, 10665-10672. [CrossRef]

22. Wei, B.; Yang, L. A review of heavy metal contaminations in urban soils, urban road dusts and agricultural soils from China. Microchem. J. 2010, 94, 99-107. [CrossRef]

23. Yang, Q.; Li, Z.; Lu, X.; Duan, Q.; Huang, L.; Bi, J. A review of soil heavy metal pollution from industrial and agricultural regions in China: Pollution and risk assessment. Sci. Total Environ. 2018, 642, 690-700. [CrossRef] [PubMed]

24. Huang, Y.; Wang, L.; Wang, W.; Li, T.; He, Z.; Yang, X. Current status of agricultural soil pollution by heavy metals in China: A meta-analysis. Sci. Total Environ. 2019, 651, 3034-3042. [CrossRef]

25. Yang, S.; Zhao, J.; Chang, S.X.; Collins, C.; Xu, J.; Liu, X. Status assessment and probabilistic health risk modeling of metals accumulation in agriculture soils across China: A synthesis. Environ. Int. 2019, 128, 165-174. [CrossRef]

26. Salomons, W. Environmental impact of metals derived from mining activities: Processes, predictions, prevention. J. Geochem. Explor. 1995, 52, 5-23. [CrossRef]

27. Schröder, W.; Holy, M.; Pesch, R.; Harmens, H.; Ilyin, I.; Steinnes, E.; Alber, R.; Aleksiayenak, Y.; Blum, O.; Coşkun, M.; et al. Are cadmium, lead and mercury con-centrations in mosses across Europe primarily determined by atmospheric deposition of these metals? J. Soils Sediments 2010, 10, 1572-1584. [CrossRef]

28. Yi, K.; Fan, W.; Chen, J.; Jiang, S.; Huang, S.; Peng, L.; Zeng, Q.; Luo, S. Annual input and output fluxes of heavy metals to paddy fields in four types of contaminated areas in Hunan Province, China. Sci. Total Environ. 2018, 634, 67-76. [CrossRef] [PubMed]

29. Khademi, H.; Abbaspour, A.; Martinez-Martinez, S.; Gabarron, M.; Shahrokh, V.; Faz, A.; Acosta, J.A. Provenance and environmental risk of windblown materials from mine tailing ponds, Murcia, Spain. Environ. Pollut. 2018, 241, 432-440. [CrossRef]

30. Yun, S.-W.; Baveye, P.C.; Kim, D.-H.; Kang, D.-H.; Lee, S.-Y.; Kong, M.-J.; Park, C.-G.; Kim, H.-D.; Son, J.; Yu, C. Analysis of metal(loid)s contamination and their continuous input in soils around a zinc smelter: Development of methodology and a case study in South Korea. Environ. Pollut. 2018, 238, 140-149. [CrossRef] [PubMed]

31. Li, Q.; Cheng, H.; Zhou, T.; Lin, C.; Guo, S. The estimated atmospheric lead emissions in China, 1990. Atmos. Environ. 2012, 60, 1-8. [CrossRef]

32. Han, L.; Gao, B.; Hao, H.; Zhou, H.; Lu, J.; Sun, K. Lead contamination in sediments in the past 20 years: A challenge for China. Sci. Total Environ. 2018, 640-641, 746-756. [CrossRef]

33. Shi, T.; Ma, J.; Zhang, Y.; Liu, C.; Hu, Y.; Gong, Y.; Wu, X.; Ju, T.; Hou, H.; Zhao, L. Status of lead accumulation in agricul-tural soils across China (1979-2016). Environ. Int. 2019, 129, 35-41. [CrossRef]

34. Laidlaw, M.A.; Mohmmad, S.M.; Gulson, B.L.; Taylor, M.P.; Kristensen, L.J.; Birch, G. Estimates of potential childhood lead exposure from contaminated soil using the US EPA IEUBK Model in Sydney, Australia. Environ. Res. 2017, 156, 781-790. [CrossRef] [PubMed]

35. Zhong, B.; Giubilato, E.; Critto, A.; Wang, L.; Marcomini, A.; Zhang, J. Probabilistic modeling of aggregate lead exposure in children of urban China using an adapted IEUBK model. Sci. Total Environ. 2017, 584-585, 259-267. [CrossRef]

36. Gilbert, S.G.; Weiss, B. A rationale for lowering the blood lead action level from 10 to 2 microg/dl. Neurotoxicology 2006, 27, 693-701. [CrossRef] [PubMed]

37. Wilhelm, M.; Heinzow, B.; Angerer, J.; Schulz, C. Reassessment of critical lead effects by the German Human Biomonitoring Commission results in suspension of the human biomonitoring values (HBM I and HBM II) for lead in blood of children and adults. Int. J. Hyg. Environ. Health 2010, 213, 265-269. [CrossRef]

38. CDC. Response to Advisory Committee on Childhood Lead Poisoning Prevention Recommendations in "Low Level Lead Exposure Harms Children: A Renewed Call for Primary Prevention; CDC: Atlanta, GA, USA, 2012.

39. Lanphear, B.P.; Hornung, R.; Khoury, J.; Yolton, K.; Baghurst, P.; Bellinger, D.C.; Canfield, R.L.; Dietrich, K.N.; Bornschein, R.; Greene, T.; et al. Low-level environ-mental lead exposure and children's intellectual function: An international pooled analysis. Environ. Health Perspect. 2005, 113, 894-899. [CrossRef] [PubMed] 